\title{
Orderings on Generalized Regular Interval Valued Fuzzy Matrices
}

\author{
P. Poongodi, C. Padmavathi, R. Vinitha, G. Hema
}

\begin{abstract}
In this paper, a special type of ordering for $\boldsymbol{k}$ - regular Interval Valued Fuzzy Matrix (IVFM) is introduced as a generalization of the minus partial ordering for regular fuzzy matrices. A set of equivalent conditions for a pair of $k$ - regular IVFM to be under this ordering are obtained. We exhibit that this ordering is preserved under similarity relation.
\end{abstract}

Keywords : Fuzzy Matrix, k-regular IVFM, minus ordering,

\section{INTRODUCTION}

A fuzzy matrix is a matrix over the fuzzy algebra $\mathrm{F}$ $=[0,1]$ under the fuzzy operations formulated by zadeh in 1965[7]. Several authors presented a number of results on fuzzy matrices. In 1977, thomson [6] studied the behavior of powers of fuzzy matrices using max-min composition. Kim and Roush have developed a theory for fuzzy matrices analogous to that for Boolean Matrices [1]. The complexity of problems in economics, engineering, environmental sciences and social sciences which cannot be solved by the well known methods of classical mathematics pose a great difficulty in today's practical world. To handle this type situation like, in the case of fuzzy mathematics, since the seminal paper by zadeh first appeared the number of researchers who are devoted to investigating both the theoretical and practical application of fuzzy sets has increased daily. This traditional fuzzy set is sometimes it may be very difficult to assign the membership value for fuzzy sets. Here, we deal with fuzzy matrices that is, matrices over the fuzzy algebra $f$ with support $[0,1]$ and fuzzy operations $\quad\{+,$.$\} defined as \mathrm{a}+\mathrm{b}=\max \{\mathrm{a}$ ,b $\}, a$. B $=\min \{a, b\}$ for all a , $b \in F$. Let $F$ m,n be the set of all mxn fuzzy matrices over F. Recently the concept of IVFM a generalization of fuzzy matrix was introduced and developed by Shyamal and Pal [5]. Meenakshi and Kaliraja have represented an IVFM as an interval matrix of its lower and upper limit fuzzy matrices[3]. In [4], Meenakshi and Poongodi have introduced the concept of $\mathrm{k}$-regular interval valued fuzzy matrix and discussed about inverses associated with a $\mathrm{k}$-regular interval valued fuzzy matrix as a generalization of results on regular fuzzy matrix developed in

Revised Manuscript Received on September 25, 2020. College of Arts and Science, Coimbatore-641035, India, poongodi_happi@rediffmail.com

(C) The Authors. Published by Blue Eyes Intelligence Engineering and Sciences Publication (BEIESP). This is an open access article under the CC BY-NC-ND license (http://creativecommons.org/licenses/by-nc-nd/4.0/) k-ordering.

* Correspondence Author

P.Poongodi*, Associate Professor, Department of Mathematics, KG

[2].A matrix $A \in F_{n}$, the set of all nxn fuzzy matrices is said to be right(left) $\mathrm{k}$ - regular if there exists $\mathrm{X}(\mathrm{Y}) \in \mathcal{F}_{\mathrm{n}}$, such that $A^{k} X A=A^{k}\left(A Y A^{k}=A^{k}\right), X(Y)$ is called a right (left) k-g inverse of $A$, where $k$ is a positive integer. By a $k$ - regular matrix, we mean that it is either right or left k- regular. In this paper, we introduce a special type of ordering for k-regular fuzzy matrices as a generalization of the minus ordering studied in [2] for regular fuzzy matrices.

\section{PRELIMINARIES}

In this section, some basic definitions and results needed are given. Let (IVFM) $)_{n}$ denotes the set of all nxn Interval Valued Fuzzy Matrices.

\section{Definition 2.1}

An Interval Valued Fuzzy Matrix (IVFM) of order mxn is defined as $A=\left(a_{i j}\right)_{m x n}$, where $a_{i j}=\left[a_{i j L}, a_{i j U}\right]$, the $i j^{\text {th }}$ element of $A$ is an interval representing the membership value. All the elements of an IVFM are intervals and all the intervals are the subintervals of the interval $[0,1]$.

For $A=\left(a_{i j}\right)=\left(\left[a_{i j L}, a_{i j U}\right]\right)$ and $B=\left(b_{i j}\right)=\left(\left[b_{i j L}, b_{i j U}\right]\right)$ of order mxn their sum denoted as $\mathrm{A}+\mathrm{B}$ defined as ,

$\mathrm{A}+\mathrm{B}=\left(\mathrm{a}_{\mathrm{ij}}+\mathrm{b}_{\mathrm{ij}}\right)=\left(\left[\left(\mathrm{a}_{\mathrm{ijL}}+\mathrm{b}_{\mathrm{ijL}}\right),\left(\mathrm{a}_{\mathrm{ijU}}+\mathrm{b}_{\mathrm{iju}}\right)\right]\right)$

For $\mathrm{A}=\left(\mathrm{a}_{\mathrm{ij}}\right)_{\mathrm{mxn}}$ and $\mathrm{B}=\left(\mathrm{b}_{\mathrm{ij}}\right)_{\mathrm{nxp}}$ their product denoted as $\mathrm{AB}$ is defined as,

$$
\left.A B=\left(c_{i j}\right)=\sum_{k=1}^{n} a_{i k} b_{k j}\right)_{\text {and }}^{j=1,2, \ldots, p ~} i . .(2.2)
$$

In particular if $\mathrm{a}_{\mathrm{ijL}}=\mathrm{a}_{\mathrm{iju}}$ and $\mathrm{b}_{\mathrm{ijL}}=\mathrm{b}_{\mathrm{iju}}$ then (2.2) reduces to the standard max. min composition of Fuzzy Matrices [1].

$\mathrm{A} \leq \mathrm{B}$ if and only if $\mathrm{a}_{\mathrm{ijL}} \leq \mathrm{b}_{\mathrm{ijL}}$ and $\mathrm{a}_{\mathrm{iju}} \leq \mathrm{b}_{\mathrm{ijU}}$

\section{Definition 2.2}

For a pair of Fuzzy Matrices $E=\left(e_{i j}\right)$ and $F=\left(f_{i j}\right)$ in $F$ $m, n$ such that $E \leq F$, let us define the interval matrix denoted as $[E, F]$, whose $i j^{\text {th }}$ entry is the interval with lower limit $e_{i j}$ and upper limit $\mathrm{f}_{\mathrm{ij}}$, that is $\left(\left[\mathrm{e}_{\mathrm{ij}}, \mathrm{f}_{\mathrm{ij}}\right]\right)$. In particular for $\mathrm{E}=\mathrm{F}$, IVFM [E,E] reduces to $\mathrm{E} \in \mathrm{F}_{\mathrm{m}, \mathrm{n}}$.

For $A=\left(a_{i j}\right)=\left(\left[a_{i j L}, a_{i j U}\right]\right) \in(I V F M)_{m n}$, let us define $A_{L}=$ $\left(\mathrm{a}_{\mathrm{ijL}}\right)$ and $\mathrm{A}_{\mathrm{U}}=\left(\mathrm{a}_{\mathrm{ijU}}\right)$.

\section{Lemma 2.3}

For $\mathrm{A}=\left[\mathrm{A}_{\mathrm{L}}, \mathrm{A}_{\mathrm{U}}\right] \in(\mathrm{IVFM})_{\mathrm{mn}}$ and $\mathrm{B}=\left[\mathrm{B}_{\mathrm{L}}, \mathrm{B}_{\mathrm{U}}\right] \in$ (IVFM $)_{\mathrm{np}}$, the following hold.

(i) $\mathrm{A}^{\mathrm{T}}=\left[\mathrm{A}_{\mathrm{L}}^{\mathrm{T}}, \mathrm{A}_{U}^{\mathrm{T}}\right]$

(ii) $\mathrm{AB}=\left[\mathrm{A}_{\mathrm{L}} \mathrm{B}_{\mathrm{L}}, \mathrm{A}_{\mathrm{U}} \mathrm{B}_{\mathrm{U}}\right]$

\section{Lemma 2.4}

For $\mathrm{A}, \mathrm{B} \in(\mathrm{IVFM})_{\mathrm{mn}}$

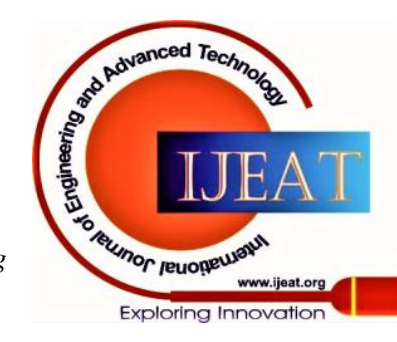




\section{Orderings on Generalized Regular Interval Valued Fuzzy Matrices}

(i) $\mathrm{R}(\mathrm{B}) \subseteq \mathrm{R}(\mathrm{A}) \Leftrightarrow \mathrm{B}=\mathrm{XA}$ for some $\mathrm{X} \in(\mathrm{IVFM})_{\mathrm{m}}$

(ii) $\mathrm{C}(\mathrm{B}) \subseteq \mathrm{C}(\mathrm{A}) \Leftrightarrow \mathrm{B}=\mathrm{AY}$ for some $\mathrm{Y} \in(\mathrm{IVFM})_{\mathrm{n}}$

\section{Lemma 2.5}

For $A \in(I V F M)_{m n}$ and $B \in(I V F M)_{n p}$, the following hold.

(i) $\mathrm{R}(\mathrm{AB}) \subseteq \mathrm{R}(\mathrm{A})$

(ii) $\mathrm{C}(\mathrm{AB}) \subseteq \mathrm{C}(\mathrm{B})$

Lemma 2.6

Let $A=\left[A_{L}, A_{U}\right]$ be an $(I V F M)_{m n}$

Then, (i) $\mathrm{R}(\mathrm{A})=\left[\mathrm{R}\left(\mathrm{A}_{\mathrm{L}}\right), \mathrm{R}\left(\mathrm{A}_{\mathrm{U}}\right)\right] \in(\mathrm{IVFM})_{1 \mathrm{n}}$

(ii) $\mathrm{C}(\mathrm{A})=\left[\mathrm{C}\left(\mathrm{A}_{\mathrm{L}}\right), \mathrm{C}\left(\mathrm{A}_{\mathrm{U}}\right)\right] \in(\mathrm{IVFM})_{1 \mathrm{~m}}$

\section{Definition 2.7}

For $\mathrm{A} \in \mathrm{F}_{\mathrm{n}}, \mathrm{B} \in \mathrm{F}_{\mathrm{n}}$; the ordering denoted as $\mathrm{A} \leq \mathrm{B}$ is defined as

$$
\mathrm{A} \leq \mathrm{B} \quad \Leftrightarrow \quad \mathrm{AX}=\mathrm{BX} \text { for some } \mathrm{X} \in \mathrm{A}\{1\}
$$$$
\text { and } \quad \mathrm{YA}=\mathrm{YB} \text { for some } \mathrm{Y} \in \mathrm{A}\{1\} \text {. }
$$

\section{Theorem 2.8}

Let $A=\left[A_{L}, A_{U}\right] \in(I V F M)_{n}$ and $k$ be a positive integer, then

$$
\begin{array}{ll}
\text { (i) } & \mathrm{X}_{\mathrm{L}} \in\left(\mathrm{A}_{\mathrm{L}}\right)\left\{1_{r}^{k}\right\} \Leftrightarrow \mathrm{X}_{\mathrm{L}}^{\mathrm{T}} \in\left(\mathrm{A}_{\mathrm{L}}\right)^{\mathrm{T}}\left\{1_{\ell}^{k}\right\} \\
\text { (ii) } & \mathrm{X}_{\mathrm{U}} \in\left(\mathrm{A}_{\mathrm{U}}\right)\left\{1_{r}^{k}\right\} \Leftrightarrow \mathrm{X}_{\mathrm{U}}^{\mathrm{T}} \in\left(\mathrm{A}_{\mathrm{U}}\right)^{\mathrm{T}}\left\{1_{\ell}^{k}\right\}
\end{array}
$$

\section{ORDERINGS ON K - REGULAR IVFM.}

In this section, we define a special type of ordering involving k-g inverses and call it as $\mathrm{k}$-ordering for k-regular Interval valued fuzzy matrices. Some basic properties on a pair of k-regular IVFM under this ordering are discussed.

\section{Definition 3.1}

A matrix $A \in(I V F M)_{n}$ is said to be right $k$ - regular if there exist a matrix $X \in(I V F M)_{n}$, such that $A^{k} X A=A^{k}$, for some positive integer $\mathrm{k}$. $\mathrm{X}$ is called a right $\mathrm{k}-\mathrm{g}$ inverse of $\mathrm{A}$. Let $A_{r}\left\{1^{k}\right\}=\left\{X / A^{k} X A=A^{k}\right\}$.

\section{Definition 3.2}

A matrix $A \in(I V F M)_{n}$ is said to be left $\mathrm{k}$ - regular if there exist a matrix $Y \in(I V F M)_{n}$, such that $A Y^{k}=A^{k}$, for some positive integer $k$. $Y$ is called a left $k-g$ inverse of $A$. Let $A_{\ell}\left\{1^{k}\right\}=\left\{Y / A Y A^{k}=A^{k}\right\}$.

In general, right $\mathrm{k}-$ regular IVFM is different from left $\mathrm{k}$ regular IVFM. Hence a right $\mathrm{k}-\mathrm{g}$ inverse need not be a left $\mathrm{k}-\mathrm{g}$ inverse.

\section{Definition 3.3}

For $\mathrm{A} \in(\mathrm{IVFM})_{\mathrm{n}}{ }^{(\mathrm{k})}, \mathrm{B} \in(\mathrm{IVFM})_{\mathrm{n}}$; the ordering denoted as $\mathrm{A}$ $k$ $\leq \mathrm{B}$ is defined as

$\mathrm{A} \underset{\leqq}{k} \mathrm{~B} \Leftrightarrow \mathrm{A}^{\mathrm{k}} \mathrm{X}=\mathrm{B}^{\mathrm{k}} \mathrm{X}$ for some $\mathrm{X} \in \mathrm{A}\left\{1_{r}^{k}\right\}$ and $\quad \mathrm{YA}^{\mathrm{k}}=\mathrm{YB}^{\mathrm{k}}$ for some $\mathrm{Y} \in \mathrm{A}\left\{1_{\ell}^{k}\right\}$.

In particular for $\mathrm{k}=1$, Definition (3.3) reduces to Definition (2.7), that is minus ordering on regular fuzzy matrices. If $\mathrm{X}$ is a g-inverse of $\mathrm{A}^{\mathrm{k}}$, then by Definition (3.3) and Definition (2.7) we have $\mathrm{A}_{\varsigma^{k}}^{k} \mathrm{~B} \Leftrightarrow \mathrm{A}^{\mathrm{k}}<\mathrm{B}^{\mathrm{k}}$. However, in general if $\mathrm{X} \in \mathrm{A}\left\{1_{r}^{k}\right\}$, then $\mathrm{X}$ need not be a $\mathrm{g}$ - inverse of $\mathrm{A}^{\mathrm{k}}$. This is illustrated in the following example.

\section{Example 3.4}

Let $\mathrm{A}=[0.3,0.5][0.7,1]$.

$$
[0.5,1] \quad[0,0]
$$

For this A

$$
A^{2}=\left(\begin{array}{ll}
{[0.5,0.7]} & {[0.3,0.5]} \\
{[0.3,0.5]} & {[0.5,1]}
\end{array}\right)
$$

For $X=\left(\begin{array}{ll}{[0.3,1]} & {[0.7,0.9]} \\ {[0.5,0.8]} & {[0,0]}\end{array}\right), \quad A^{2} X A=A^{2}$.

Hence $\mathrm{X} \in \mathrm{A}\left\{1_{r}^{2}\right\}$ and $\mathrm{A}$ is 2 - regular,

but $A^{2} X A^{2}=\left(\begin{array}{ll}{[0.3,0.3]} & {[0.5,0.5]} \\ {[0.5,0.5]} & {[0.3,0.5]}\end{array}\right) \neq A^{2}$,

Therefore $X$ is not in $A^{2}\{1\}$. Thus $X$ is a 2-g- inverse of $A$ but $\mathrm{X}$ is not a $\mathrm{g}$ - inverse for $\mathrm{A}^{2}$.

\section{Lemma 3.5}

For $\mathrm{A} \in(\mathrm{IVFM})_{\mathrm{n}}{ }^{(\mathrm{k})}$ and $\mathrm{B} \in(\mathrm{IVFM})_{\mathrm{n}}$; the following are equivalent.

(i) $\quad \mathrm{A}_{\leq}^{k} \mathrm{~B}$

(ii) $\quad \mathrm{A}^{\mathrm{k}}=\mathrm{B}^{\mathrm{k}} \mathrm{X} \mathrm{A}=\mathrm{AYB}^{\mathrm{k}} \quad$ for some $\mathrm{X}, \mathrm{Y} \in \mathrm{A}\left\{1^{\mathrm{k}}\right\}$

Proof: (i) $\Rightarrow$ (ii)

$$
\begin{aligned}
& \mathrm{A} \underset{\leq}{k} \mathrm{~B} \Rightarrow \mathrm{A}^{\mathrm{k}} \mathrm{X}=\mathrm{B}^{\mathrm{k}} \mathrm{X} \quad \text { for some } \mathrm{X} \in \mathrm{A}\left\{1_{r}^{k}\right\} \\
& \text { and } \quad \mathrm{YA}^{\mathrm{k}}=\mathrm{YB}^{\mathrm{k}} \quad \text { for some } \mathrm{Y} \in \mathrm{A}\left\{1_{\ell}^{k}\right\}
\end{aligned}
$$

Now,

$$
\begin{array}{ll}
\mathrm{A}^{\mathrm{k}}=\left(\mathrm{A}^{\mathrm{k}} \mathrm{X}\right) \mathrm{A}=\mathrm{B}^{\mathrm{k}} \mathrm{X} \mathrm{A} & \text { for some } \mathrm{X} \in \mathrm{A}\left\{1_{r}^{k}\right\} \\
\mathrm{A}^{\mathrm{k}}=\mathrm{A}\left(\mathrm{YA}^{\mathrm{k}}\right)=\mathrm{AY} \mathrm{B}^{\mathrm{k}} & \text { for some } \mathrm{Y} \in \mathrm{A}\left\{1_{\ell}^{k}\right\} \\
\mathrm{A}^{\mathrm{k}}=\mathrm{B}^{\mathrm{k}} \mathrm{X} \mathrm{A}=\mathrm{AY} \mathrm{B} \mathrm{B}^{\mathrm{k}} & \text { for some } \mathrm{X}, \mathrm{Y} \in \mathrm{A}\left\{1^{\mathrm{k}}\right\}
\end{array}
$$

Thus (ii) holds.

(ii) $\Rightarrow$ (i)

Let $\mathrm{Z}=\mathrm{XAX}$ for $\mathrm{X} \in \mathrm{A}\left\{1_{r}^{k}\right\}$

$A^{k} Z A=A^{k}(X A X) A=\left(A^{k} X A\right) X A=A^{k} X A=A^{k}$

$$
\Rightarrow \mathrm{Z} \in \mathrm{A}\left\{1_{r}^{k}\right\}
$$

Similarly, $\mathrm{AZA}^{\mathrm{k}}=\mathrm{A}^{\mathrm{k}}$ for $\mathrm{Z}=\mathrm{YAY}$ for $\mathrm{Y} \in \mathrm{A}\left\{1_{\mathscr{\ell}}^{k}\right\}$

$$
\Rightarrow \mathrm{Z} \in \mathrm{A}\left\{1_{\ell}^{k}\right\}
$$

Thus, for $\mathrm{X} \in \mathrm{A}\left\{1^{\mathrm{k}}\right\}, \mathrm{Z}=\mathrm{XAX} \in \mathrm{A}\left\{1_{r}^{k}\right\}$ when $\mathrm{X} \in \mathrm{A}\left\{1_{r}^{k}\right\}$ and $\mathrm{Z}=\mathrm{XAX} \in \mathrm{A}\left\{1_{\ell}^{k}\right\}$ when $\mathrm{X} \in \mathrm{A}\left\{1_{\ell}^{k}\right\}$.

Now, $\quad A^{k} Z \quad=A^{k}(X A X)=\left(A^{k} X A\right) X$

$$
=A^{k} X=\left(B^{k} X A\right) X=B^{k}(X A X)=B^{k} Z
$$

Hence $\quad A^{k} Z=B^{k} Z$ for some $\mathrm{Z} \in \mathrm{A}\left\{1_{r}^{k}\right\}$.

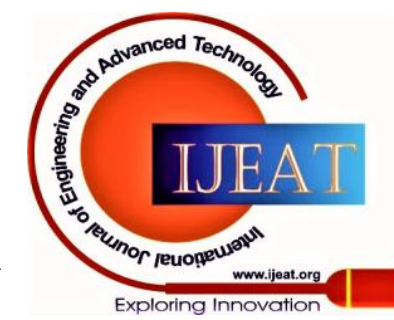


Similarly, $\mathrm{ZA}^{\mathrm{k}}=\mathrm{ZB}^{\mathrm{k}}$ for some $\mathrm{Z} \in \mathrm{A}\left\{1_{\ell}^{k}\right\}$.

Therefore $\mathrm{A} \underset{\leqq}{k}$ B. Thus (i) holds.

Hence the theorem.

\section{Corollary 3.6}

For $A \in F_{n}^{(k)}$ and $B \in F_{n}$; the following are equivalent.

(i) $\quad \mathrm{A} \underset{\mathrm{B}}{k}$

(ii) $\quad \mathrm{A}^{\mathrm{k}}=\mathrm{B}^{\mathrm{k}} \mathrm{X} \mathrm{A}=\mathrm{AYB}^{\mathrm{k}}$ for some $\mathrm{X}, \mathrm{Y} \in \mathrm{A}\left\{1^{\mathrm{k}}\right\}$

\section{Lemma 3.7}

For $\mathrm{A}, \mathrm{B} \in(\mathrm{IVFM})_{\mathrm{n}}{ }^{(\mathrm{k})}$

(i) If $\mathrm{B}$ is right $\mathrm{k}$-regular and $\mathrm{R}\left(\mathrm{A}^{\mathrm{k}}\right) \subseteq \mathrm{R}\left(\mathrm{B}^{\mathrm{k}}\right)$ then $\mathrm{A}^{\mathrm{k}}=$ $A^{k} B^{-} B$ for each right k-g inverse $B^{-}$of $B$.

(ii) If $\mathrm{B}$ is left k-regular and $\mathrm{C}\left(\mathrm{A}^{\mathrm{k}}\right) \subseteq \mathrm{C}\left(\mathrm{B}^{\mathrm{k}}\right)$ then $\mathrm{A}^{\mathrm{k}}=\mathrm{BB}^{-} \mathrm{A}^{\mathrm{k}}$ for each left k-g inverse $B^{-}$of $B$.

\section{Proof:}

(i) $\mathrm{R}\left(\mathrm{A}^{\mathrm{k}}\right) \subseteq \mathrm{R}\left(\mathrm{B}^{\mathrm{k}}\right) \Rightarrow \mathrm{A}^{\mathrm{k}}=\mathrm{XB} \mathrm{B}^{\mathrm{k}}$

$$
\begin{aligned}
& =\mathrm{XB}^{\mathrm{k}} \mathrm{B}^{-} \mathrm{B} \\
& =\mathrm{A}^{\mathrm{k}} \mathrm{B}^{-} \mathrm{B}
\end{aligned}
$$

( By Lemma (2.4))

Thus (i) holds.

(ii) $\mathrm{C}\left(\mathrm{A}^{\mathrm{k}}\right) \subseteq \mathrm{C}\left(\mathrm{B}^{\mathrm{k}}\right) \Rightarrow \mathrm{A}^{\mathrm{k}}=\mathrm{B}^{\mathrm{k}} \mathrm{Y}$

$$
\begin{aligned}
& =\mathrm{BB}^{-} \mathrm{B}^{\mathrm{k}} \mathrm{Y} \\
& =\mathrm{BB}^{-} \mathrm{A}^{\mathrm{k}}
\end{aligned}
$$

( By Lemma (2.4)) for each $\mathrm{B}^{-} \in \mathrm{B}\left\{1_{\ell}^{k}\right\}$.

Thus (ii) holds.

\section{Corollary 3.8}

For $\mathrm{A}, \mathrm{B} \in \mathrm{F}_{\mathrm{n}}{ }^{(\mathrm{k})}$

(i) If $\mathrm{B}$ is right $\mathrm{k}$-regular and $\mathrm{R}\left(\mathrm{A}^{\mathrm{k}}\right) \subseteq \mathrm{R}\left(\mathrm{B}^{\mathrm{k}}\right)$ then $\mathrm{A}^{\mathrm{k}}=\mathrm{A}^{\mathrm{k}} \mathrm{B}^{-} \mathrm{B}$ for each right $\mathrm{k}$-g inverse $\mathrm{B}^{-}$of $\mathrm{B}$.

(ii) If $\mathrm{B}$ is left k-regular and $\mathrm{C}\left(\mathrm{A}^{\mathrm{k}}\right) \subseteq \mathrm{C}\left(\mathrm{B}^{\mathrm{k}}\right)$ then $\mathrm{A}^{\mathrm{k}}=\mathrm{BB}^{-} \mathrm{A}^{\mathrm{k}}$ for each left k-g inverse $B^{-}$of $B$.

\section{Theorem 3.9}

$$
\text { For } \mathrm{A}, \mathrm{B} \in(\mathrm{IVFM})_{\mathrm{n}}{ }^{(\mathrm{k})} \text {, if } \mathrm{A}_{\leq}^{k} \mathrm{~B} \text { then } \mathrm{R}\left(\mathrm{A}^{\mathrm{k}}\right) \subseteq \mathrm{R}\left(\mathrm{B}^{\mathrm{k}}\right) \text {, }
$$

$\mathrm{C}\left(\mathrm{A}^{\mathrm{k}}\right) \subseteq \mathrm{C}\left(\mathrm{B}^{\mathrm{k}}\right)$ and $\mathrm{A}^{\mathrm{k}} \mathrm{X} \mathrm{B}=\mathrm{A}^{\mathrm{k}}=\mathrm{BY} \mathrm{A}^{\mathrm{k}}$ for each $\mathrm{X} \in \mathrm{B}\left\{1_{r}^{k}\right\}$ and for each $\mathrm{Y} \in \mathrm{B}\left\{1_{\ell}^{k}\right\}$.

\section{Proof:}

$\mathrm{A}{ }_{\leq}^{k} \mathrm{~B} \Rightarrow \mathrm{A}^{\mathrm{k}}=\mathrm{AY} \mathrm{B}^{\mathrm{k}}=\mathrm{B}^{\mathrm{k}} \mathrm{X} \mathrm{A} \quad$ (By Lemma (3.5))

$\Rightarrow \mathrm{A}^{\mathrm{k}}=\mathrm{VB}^{\mathrm{k}}=\mathrm{B}^{\mathrm{k}} \mathrm{U}$, where $\mathrm{V}=\mathrm{AY}$ and $\mathrm{U}=\mathrm{XA}$

$\Rightarrow \mathrm{R}\left(\mathrm{A}^{\mathrm{k}}\right) \subseteq \mathrm{R}\left(\mathrm{B}^{\mathrm{k}}\right)$ and $\mathrm{C}\left(\mathrm{A}^{\mathrm{k}}\right) \subseteq \mathrm{C}\left(\mathrm{B}^{\mathrm{k}}\right)$ ( By Lemma (2.4)) $\Rightarrow \mathrm{A}^{\mathrm{k}} \mathrm{XB}=\mathrm{A}^{\mathrm{k}}=\mathrm{BY}^{\mathrm{k}}$ for each $\mathrm{X} \in \mathrm{B}\left\{1_{r}^{k}\right\}$ and for each $\mathrm{Y} \in \mathrm{B}\left\{1_{\ell}^{k}\right\}$ (By Lemma 3.7)

\section{Corollary 3.10}

For $\mathrm{A}, \mathrm{B} \in \mathrm{F}_{\mathrm{n}}^{(\mathrm{k})}$, if $\mathrm{A} \varliminf^{k} \mathrm{~B}$ then $\mathrm{R}\left(\mathrm{A}^{\mathrm{k}}\right) \subseteq \mathrm{R}\left(\mathrm{B}^{\mathrm{k}}\right), \mathrm{C}\left(\mathrm{A}^{\mathrm{k}}\right) \subseteq$ $\mathrm{C}\left(\mathrm{B}^{\mathrm{k}}\right)$ and $\mathrm{A}^{\mathrm{k}} \mathrm{X} \mathrm{B}=\mathrm{A}^{\mathrm{k}}=\mathrm{BY} \mathrm{A}^{\mathrm{k}}$ for each $\mathrm{X} \in \mathrm{B}\left\{1_{r}^{k}\right\}$ and for each $\mathrm{Y} \in \mathrm{B}\left\{1_{\ell}^{k}\right\}$.

\section{Theorem 3.11}

For $\mathrm{A}, \mathrm{B} \in(\mathrm{IVFM})_{\mathrm{n}}{ }^{(\mathrm{k})}$, the following hold. (i) $\mathrm{A} \underset{\leq}{k} \mathrm{~A}$

(ii) $\mathrm{A} \underset{5}{\mathrm{k}} \mathrm{B}$ and $\mathrm{B} \stackrel{\mathrm{A}}{k}^{\mathrm{A}}$ then $\mathrm{A}^{\mathrm{k}}=\mathrm{B}^{\mathrm{k}}$

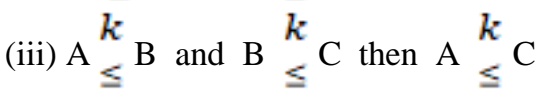

Proof :

(i) $\mathrm{A} \underset{\leq}{k} \mathrm{~A}$ is trivial.

(ii) $\mathrm{A} \underset{\leq}{k} \mathrm{~B} \Rightarrow \mathrm{A}^{\mathrm{k}}=\mathrm{B}^{\mathrm{k}} \mathrm{XA} \quad$ for $\mathrm{X} \in \mathrm{A}\left\{1_{r}^{k}\right\}$ ( By Lemma 3.5)

$\mathrm{B} \leq^{k} \mathrm{~A} \Rightarrow \mathrm{B}^{\mathrm{k}}=\mathrm{BY}^{\mathrm{k}}$ f or $\mathrm{Y} \in \mathrm{A}\left\{1_{\ell}^{k}\right\} \quad$ ( By Lemma 3.5)

Now, $A^{k}=B^{k} X A=\left(B Y A^{k}\right) X A=B Y\left(A^{k} X A\right)=B Y A^{k}=B^{k}$

Hence, $\mathrm{A}_{\leq}^{k} \mathrm{~B}$ and $\mathrm{B} \underset{\leq}{k} \mathrm{~A} \Rightarrow \mathrm{A}^{\mathrm{k}}=\mathrm{B}^{\mathrm{k}}$

(iii) $\mathrm{A}_{\leq}^{k} \mathrm{~B} \Rightarrow \mathrm{A}^{\mathrm{k}}=\mathrm{A}^{\mathrm{k}} \mathrm{B}^{-} \mathrm{B}=\mathrm{BB}^{-} \mathrm{A}^{\mathrm{k}}$ (By Theorem (3.7) and Lemma (3.5)(i))

$$
\mathrm{B}_{\leqq}^{k} \mathrm{~A} \Rightarrow \mathrm{B}^{\mathrm{k}}=\mathrm{C}^{\mathrm{k}} \mathrm{B}^{-} \mathrm{B}=\mathrm{BB}^{-} \mathrm{C}^{\mathrm{k}} \text { (By Theorem (3.5) and }
$$

Lemma (3.7)(i))

Let $\mathrm{Z}=\mathrm{B}^{-} \mathrm{BX}$ for $\mathrm{B}^{-} \in \mathrm{B}\left\{1_{r}^{k}\right\}$ and $\mathrm{X} \in \mathrm{A}\left\{1_{r}^{k}\right\}$

Then, $A^{k} Z A=\left(A^{k} B^{-} B\right) X A=A^{k} X A=A^{k}$

Therefore, $\mathrm{Z} \in \mathrm{A}\left\{1_{r}^{k}\right\}$

If $\mathrm{Z}=\mathrm{YBB}^{-}$for $\mathrm{B}^{-} \in \mathrm{B}\left\{1_{\ell}^{k}\right\}$ and $\mathrm{Y} \in \mathrm{A}\left\{1_{\ell}^{k}\right\}$ then it follows that $\mathrm{AZA}^{\mathrm{k}}=\mathrm{A}^{\mathrm{k}}$

Therefore, $\mathrm{Z} \in \mathrm{A}\left\{1_{\ell}^{k}\right\}$.

Since $\mathrm{A}_{\leq}^{k} \mathrm{~B}$ and $\mathrm{B} \underset{\leqq}{k} \mathrm{C}$, applying Theorem (5.2.7), we have $A^{k} Z=A^{k}\left(B^{-} B X\right)$

$$
\begin{aligned}
& =\left(A^{k} B^{-} B\right) X \\
= & A^{k} X \\
= & B^{k} X \\
= & \left(C^{k} B^{-} B\right) X \\
= & \left(B^{-} B^{k}\right) X \\
= & C^{k}\left(B^{-} B X\right) \\
= & C^{k} Z \quad \text { for some } Z \in A\left\{1_{r}^{k}\right\} .
\end{aligned}
$$

(By Theorem (3.7))

( By Lemma (3.5))

and $\mathrm{ZA}^{\mathrm{k}}=\mathrm{ZC}^{\mathrm{k}}$ for some $\mathrm{Z} \in \mathrm{A}\left\{1_{\ell}^{k}\right\}$ can be proved in a similar manner.

Hence, $\mathrm{Z} \in \mathrm{A}\left\{1^{\mathrm{k}}\right\}$ with $\mathrm{A}^{\mathrm{k}} \mathrm{Z}=\mathrm{C}^{\mathrm{k}} \mathrm{Z}$ and $\mathrm{ZA}^{\mathrm{k}}=\mathrm{Z} \mathrm{C}^{\mathrm{k}}$. Therefore $\mathrm{A}_{\leq}^{k} \mathrm{C}$.

Corollary 3.12

For $\mathrm{A}, \mathrm{B} \in \mathrm{F}_{\mathrm{n}}{ }^{(\mathrm{k})}$, the following hold.

(i) $\mathrm{A} \underset{\leqslant}{k} \mathrm{~A}$

(ii) $\mathrm{A} \sum_{\leq}^{k} \mathrm{~B}$ and $\mathrm{B} \stackrel{\mathrm{s}}{k}^{\mathrm{A}}$ then $\mathrm{A}^{\mathrm{k}}=\mathrm{B}^{\mathrm{k}}$

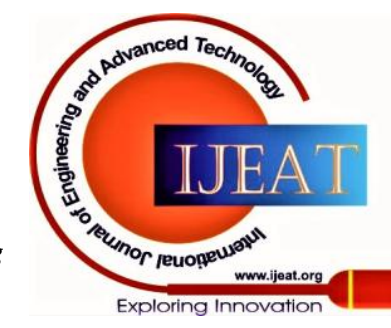




\section{Orderings on Generalized Regular Interval Valued Fuzzy Matrices}

(ii) $\quad \mathrm{A}_{\leq}^{k} \mathrm{~B}$ and $\mathrm{B} \underset{\leq}{k} \mathrm{C}$ then $\mathrm{A}_{\leq}^{k} \mathrm{C}$

\section{PROPERTIES OF K - ORDERING ON K-REGULAR IVFM.}

\section{Proposition 4.1}

For $\mathrm{A}, \mathrm{B} \in(\mathrm{IVFM})_{\mathrm{n}}{ }^{(\mathrm{k})}, \mathrm{A}_{\leq}^{k} \mathrm{~B} \Leftrightarrow \mathrm{A}^{\mathrm{T}}{ }_{\varliminf^{k}}^{k} \mathrm{~B}^{\mathrm{T}}$

Proof.

$\mathrm{A}_{\leq}^{k} \mathrm{~B} \Leftrightarrow \mathrm{A}^{\mathrm{k}} \mathrm{A}^{-}=\mathrm{B}^{\mathrm{k}} \mathrm{A}^{-} \quad$ for some $\mathrm{A}^{-} \in \mathrm{A}\left\{1_{r}^{k}\right\}$ and $\mathrm{A}^{-} \mathrm{A}^{\mathrm{k}}=\mathrm{A}^{-} \mathrm{B}^{\mathrm{k}} \quad$ for some $\mathrm{A}^{-} \in \mathrm{A}\left\{1_{\ell}^{k}\right\}$

By Lemma (2.8), $\mathrm{A}^{-} \in \mathrm{A}\left\{1_{r}^{k}\right\} \Leftrightarrow\left(\mathrm{A}^{-}\right)^{\mathrm{T}} \in \mathrm{A}\left\{1_{\mathfrak{l}^{k}}^{k}\right\}$.

$$
A^{k} A^{-}=B^{k} A^{-}
$$

$\Leftrightarrow\left(\mathrm{A}^{\mathrm{k}} \mathrm{A}^{-}\right)^{\mathrm{T}}=\left(\mathrm{B}^{\mathrm{k}} \mathrm{A}^{-}\right)^{\mathrm{T}}$

$\Leftrightarrow\left(A^{-}\right)^{T}\left(A^{k}\right)^{T}=\left(A^{-}\right)^{T}\left(B^{k}\right)^{T}$

$\Leftrightarrow\left(A^{T}\right)^{-}\left(A^{k}\right)^{T}=\left(A^{T}\right)^{-}\left(B^{k}\right)^{T}$

Thus, $\quad A^{k} A^{-}=B^{k} A^{-} \Leftrightarrow\left(A^{T}\right)^{-}\left(A^{k}\right)^{T}=\left(A^{T}\right)^{-}\left(B^{k}\right)^{T}$

Similarly, $A^{-} A^{k}=A^{-} B^{k} \Leftrightarrow\left(A^{k}\right)^{T}\left(A^{T}\right)^{-}=\left(B^{k}\right)^{T}\left(A^{T}\right)^{-}$

Hence $\mathrm{A}_{\leq}^{k} \mathrm{~B} \Leftrightarrow \mathrm{A}^{\mathrm{T}}{ }_{\leq}^{k} \mathrm{~B}^{\mathrm{T}}$

\section{Corollary 4.2}

For $\mathrm{A}, \mathrm{B} \in \mathrm{F}_{\mathrm{n}}{ }^{(\mathrm{k})}, \mathrm{A} \underset{\leq}{k} \mathrm{~B} \Leftrightarrow \mathrm{A}^{\mathrm{T}} \underset{\leq}{k} \mathrm{~B}^{\mathrm{T}}$

\section{Proposition 4.3} permutation matrix $\mathrm{P}$.

\section{Proof:}

Since A is k-regular, it can be verified that $\mathrm{PAP}^{\mathrm{T}}$ is $\mathrm{k}$ - regular and $\mathrm{PA}^{-} \mathrm{P}^{\mathrm{T}}$ is a k-g inverse of $\mathrm{PAP}^{\mathrm{T}}$ for each $\mathrm{k}-\mathrm{g}$ inverse $\mathrm{A}^{-}$of A.

$$
\text { Now, } \begin{aligned}
\left(\mathrm{PAP}^{\mathrm{T}}\right)^{-}\left(\mathrm{PAP}^{\mathrm{T}}\right)^{\mathrm{k}}=\mathrm{PA}^{-} \mathrm{P}^{\mathrm{T}} \mathrm{PA}^{\mathrm{k}} \mathrm{P}^{\mathrm{T}} \\
=\mathrm{PA}^{-}\left(\mathrm{P}^{\mathrm{T}} \mathrm{P}\right) \mathrm{A}^{\mathrm{k}} \mathrm{P}^{\mathrm{T}} \\
=\mathrm{P}^{-}\left(\mathrm{A}^{-} \mathrm{A}^{\mathrm{k}}\right) \mathrm{P}^{\mathrm{T}} \\
=\mathrm{P}^{-}\left(\mathrm{A}^{-} \mathrm{B}^{\mathrm{k}}\right) \mathrm{P}^{\mathrm{T}} \\
=\left(\mathrm{PA}^{-} \mathrm{P}^{\mathrm{T}}\right)\left(\mathrm{PB}^{\mathrm{k}} \mathrm{P}^{\mathrm{T}}\right) \\
=\left(\mathrm{PAP}^{\mathrm{T}}\right)^{-}\left(\mathrm{PBP}^{\mathrm{T}}\right)^{\mathrm{k}}
\end{aligned}
$$

Hence $\quad\left(\mathrm{PAP}^{\mathrm{T}}\right)^{-}\left(\mathrm{PAP}^{\mathrm{T}}\right)^{\mathrm{k}}=\left(\mathrm{PAP}^{\mathrm{T}}\right)^{-}\left(\mathrm{PBP}^{\mathrm{T}}\right)^{\mathrm{k}}$

Similarly $\left(\mathrm{PAP}^{\mathrm{T}}\right)^{\mathrm{k}}\left(\mathrm{PAP}^{\mathrm{T}}\right)^{-}=\left(\mathrm{PBP}^{\mathrm{T}}\right)^{\mathrm{k}}\left(\mathrm{PAP}^{\mathrm{T}}\right)^{-}$

Conversely, if $\left(\mathrm{PAP}^{\mathrm{T}}\right) \underset{\leq}{k}\left(\mathrm{PBP}^{\mathrm{T}}\right)$, then by the preceding part, $\mathrm{A}=\mathrm{P}^{\mathrm{T}}\left(\mathrm{PAP}^{\mathrm{T}}\right) \mathrm{P} \underset{\leq}{k} \mathrm{P}^{\mathrm{T}}\left(\mathrm{PBP}^{\mathrm{T}}\right) \mathrm{P}=\mathrm{B}$

Thus $\mathrm{A}_{\leq}^{k} \mathrm{~B}$.

\section{Corollary 4.4}

For $\mathrm{A}, \mathrm{B} \in \mathrm{F}_{\mathrm{n}}^{\left({ }^{k}\right)}, \mathrm{A}_{\leq}^{k} \mathrm{~B} \Leftrightarrow \mathrm{PAP}^{\mathrm{T}} \stackrel{k}{k^{\prime}} \mathrm{PBP}^{\mathrm{T}}$ for some permutation matrix $\mathrm{P}$.

\section{Proposition 4.5}

For $\mathrm{A}, \mathrm{B} \in(\mathrm{IVFM})_{\mathrm{n}}{ }^{(\mathrm{k})}, \mathrm{A} \underset{\leq}{k} \mathrm{~B} \Leftrightarrow \mathrm{PAP}^{\mathrm{T}} \stackrel{k}{k} \mathrm{PBP}^{\mathrm{T}}$ for some

Hence $\left(\mathrm{PAP}^{\mathrm{T}}\right)_{\leq}^{k}\left(\mathrm{PBP}^{\mathrm{T}}\right)$

For $\mathrm{A}, \mathrm{B} \in(\mathrm{IVFM})_{\mathrm{n}}{ }^{\left({ }^{k}\right)}$, if $\mathrm{A}_{\leq}^{k} \mathrm{~B}$ with $\mathrm{B}^{\mathrm{k}}$ is idempotent, then $\mathrm{A}^{\mathrm{k}}$ is idempotent.

Proof: Since $\mathrm{A}_{\leq}^{k}$ B, By Lemma (3.5)

$$
\begin{aligned}
A^{2 k} & =A^{k} A^{k} \\
& =\left(A Y B^{k}\right)\left(B^{k} X A\right) \\
& =A Y\left(B^{2 k}\right) X A=\left(A Y B^{k}\right) X A=A^{k} X A=A^{k}
\end{aligned}
$$

\section{Corollary 4.6}

For $\mathrm{A}, \mathrm{B} \in \mathrm{F}_{\mathrm{n}}{ }^{\mathrm{k})}$, if $\mathrm{A}_{\leq}^{k} \mathrm{~B}$ with $\mathrm{B}^{\mathrm{k}}$ is idempotent, then $\mathrm{A}^{\mathrm{k}}$ is idempotent.

\section{Remark 4.7}

In the above Proposition (4.5), if $\mathrm{A}_{\leq}^{k} \mathrm{~B}$ with A idempotent then $\mathrm{B}$ need not be idempotent. This is illustrated in the following.

$$
\begin{aligned}
& \begin{array}{l}
\text { Example 4.8 } \\
\text { Consider } A
\end{array}=\left(\begin{array}{ll}
{[0.5,1]} & {[0.5,1]} \\
{[0.5,1]} & {[0.5,1]}
\end{array}\right) \\
& \text { and } B=\left(\begin{array}{ll}
{[0,0]} & {[0.5,1]} \\
0.5,1] & {[0,0]}
\end{array}\right)
\end{aligned}
$$

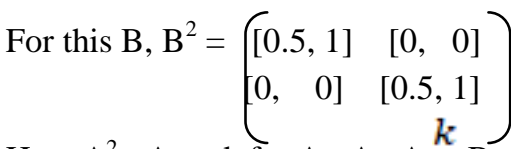

Here $\mathrm{A}^{2}=\mathrm{A}$ and for $\mathrm{A}^{-}=\mathrm{A}, \mathrm{A}_{\leq}^{k} \mathrm{~B}$, but $\mathrm{B}$ is not idempotent. Since $B^{2} \neq B$.

\section{Proposition 4.9}

For $\mathrm{A}, \mathrm{B} \in(\mathrm{IVFM})_{\mathrm{n}}{ }^{(\mathrm{k})}$, if $\mathrm{A}_{\leq}^{k} \mathrm{~B}$ then $\mathrm{B}^{\mathrm{k}}=0$ implies $\mathrm{A}^{\mathrm{k}}=0$.

Proof:

Since $\mathrm{A}_{\leq}^{k} \mathrm{~B} \Rightarrow \mathrm{A}^{\mathrm{k}}=\mathrm{AYB}^{\mathrm{k}} \quad$ (By Lemma (3.5))

$$
=0
$$

\section{Corollary 4.10}

For $\mathrm{A}, \mathrm{B} \in \mathrm{F}_{\mathrm{n}}{ }^{(\mathrm{k})}$, if $\mathrm{A}_{\leq}^{k} \mathrm{~B}$ then $\mathrm{B}^{\mathrm{k}}=0$ implies $\mathrm{A}^{\mathrm{k}}=0$.

\section{Conclusion}

Ordering principles are crucial for categorizing and ranking real world problems. This article provides a special type of ordering named $\mathrm{k}$ - ordering which has wide application in fuzzy matrices. This paper is an extension of minus ordering in fuzzy matrices to k-regular fuzzy matrices. So there is a scope to investigate this k-ordering for intuitionistic fuzzy matrices as well as fuzzy soft matrices also.

\section{ACKNOWLEDGMENT}

Published By:

Blue Eyes Intelligence Engineering

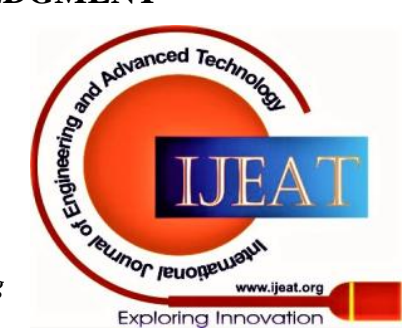


We wish to thank Dr.AR.Meenakshi (Ph.D guide) for her valuable guidance and also we thank Faculty of Mathematics Department KG college of Arts and science for their endless support and encouragement.

\section{REFERENCES}

1. K.H. Kim and F.W. Roush, "Generalized fuzzy matrices" Fuzzy sets and systems, 4, 1980, $293-315$.

2. R. Meenakshi and C.Inbam , "The Minus Partial Order in Fuzzy Matrices” The Journal of Fuzzy Mathematics vol.12, No.3, 2004, 695 -700 .

3. Meenakshi, AR., and Kaliraja,M., "Regular Interval Valued Fuzzy Matrices” Advances in Fuzzy Mathematics, Vol 5, No 1, 2010, 7 -15 .

4. A.R.Meenakshi, and P.Poongodi, Generalized Regular Interval-Valued Fuzzy Matrices, International Journal of Fuzzy Mathematics and Systems, 2( 1) (2012), 29-36.

5. Shyamal.A.K., and Pal. M., “Interval Valued Fuzzy Matrices” Journal of Fuzzy Mathematics, Vol 14, No 3, 2006, 582 - 592.

6. Thomason, M.G., "Convergence of powers of fuzzy matrix" , J.Math Anal. Appl. 57, 1977, 476 - 480.

7. Zadeh L.A., “ Fuzzy sets, Information and Control”, 8: 1965, 338 353.

\section{AUTHORS PROFILE}

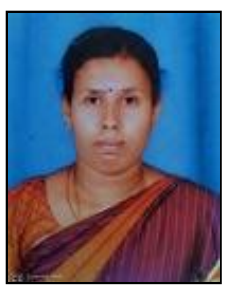

Poongodi is a Associate Professor in the Department of Mathematics at KG College of Arts and Science, Coimbatore, Tamilnadu, India. She has completed her Ph.D during the year 2009 - 2012. She got nearly ten years of teaching experience in various colleges. Also she published 10 research article in various scopus indexed and International level journals. Her current research areas are Fuzzy Algebra, Fuzzy Graph Theory, Fuzzy Logic and Interval valued and Intuitionistic fuzzy matrices.

Email:poongodi_happi@rediff.com

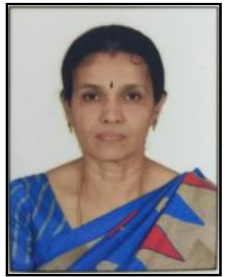

Padmavathi is a Assistant Professor in the Department of Mathematics at KG College of Arts and Science, Coimbatore, Tamilnadu, India. She got nearly Fourteen years of teaching experience in various colleges. Also she published 1 research article in UGC CARE journal. Her current research areas are Fuzzy Algebra, Fuzzy Graph Theory, Ordinary Differential Equations and Interval valued and Intuitionistic fuzzy matrices.

Email:padmavathi.c@rediff.com

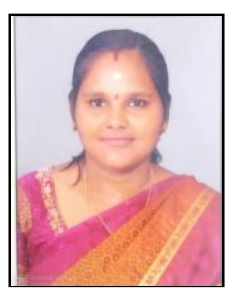

Vinitha is a Assistant Professor in the Department of Mathematics at KG College of Arts and Science, Coimbatore, Tamilnadu, India. She got nearly Four years of teaching experience in various colleges. Also she published 4 research article in various National and International level journals. Her current research areas are Fuzzy Graph Theory, Fuzzy Logic and Interval valued and Intuitionistic fuzzy matrices.

Email:vinitha.r@kgcas.com

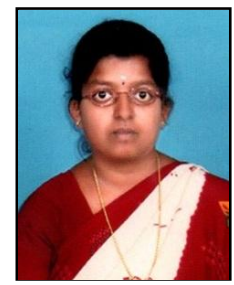

Hema is a Assistant Professor in the Department of Mathematics at KG College of Arts and Science, Coimbatore, Tamilnadu, India. She got nearly 8 years of teaching experience in various colleges. Also she published one research article in International level journal. Her current research areas are Fuzzy Graph Theory, Fuzzy Algebra and Interval valued and Intuitionistic fuzzy matrices.

Email:hemag10985@gmail.com

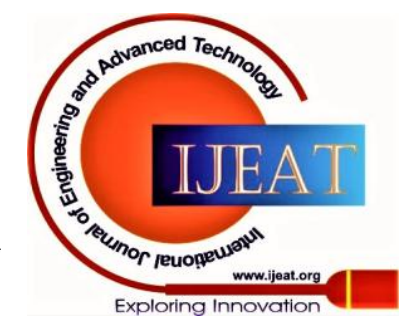

